\title{
PENGEMBANGAN PANDUAN PELATIHAN CREATIVE PROBLEM SOLVING UNTUK MENCEGAH BULLYING DI SMP
}

\author{
Triwibowo Probo Sukarno, Dany Moenindyah Handarini \\ Bimbingan dan Konseling-Fakultas Ilmu Pendidikan-Universitas Negeri Malang,-Jl. Semarang No. 5 Malang \\ E-mail: triwibowokonselor@gmail.com
}

\begin{abstract}
This research aims to developing the creative problem solving manual for preventing bullying among junior high school students which acceptable on accuracy, utility, and implementatively. This research method is adapted from procedural research and development Borg \& Gall model (1983). Expert and prospective user analyzed by inter-rater agreement (Grinnell, 1988). Agreement result of 3 guidance and counseling experts from accuracy aspect is high, utility is high, and implementatiely is very high. Agreement of 3 prospective users from accuracy is high, utility is high, and implementatively is very high. The conclusion of the test is, this training guide product acceptable.
\end{abstract}

Keywords: Training guide; creative problem solving; bullying

\begin{abstract}
Abstrak: Penelitian ini bertujuan untuk menghasilkan produk berupa panduan pelatihan creative problem solving untuk mencegah bullying di SMP yang memenuhi kriteria keberterimaan berupa ketepatan, kegunaan, dan keterlaksanaan. Metode penelitian ini diadaptasi dari model Research and Development (R\&D) prosedural Borg \& Gall (1983). Uji ahli dan calon pengguna berupa angket dianalisis menggunakan inter-rater agreement (Grinnell, 1988). Hasil kesepakatan oleh 3 ahli bimbingan dan konseling pada aspek ketepatan tinggi, kegunaan tinggi, dan keterlaksanaan sangat tinggi. Kesepakatan oleh 3 calon pengguna pada aspek ketepatan tinggi, kegunaan tinggi, dan keterksanaan sangat tinggi. Berdasarkan uji tersebut dapat disimpulkan bahwa produk panduan pelatihan telah memenuhi kriteria keberterimaan.
\end{abstract}

Kata kunci: Panduan pelatihan; creative problem solving; bullying.

Bullying adalah perilaku antisosial yang sering terjadi di lingkungan pendidikan. Selama bertahun-tahun, kasus bullying selalu menjadi bagian yang tidak terpisahkan antar ikatan manusia dengan konteks sosial dan kultural yang berbeda-beda. Guru, siswa, bahkan orang tua merupakan kelompok manusia yang biasa memunculkan perilaku bullying sebagai bagian dari interaksi antar individu.

Ada beberapa definisi bullying dari ahli. Besag (1994) mendefinisikan bullying adalah penyerangan yang berulang-ulang secara fisik, psikis, sosial, dan verbal oleh individu yang mempunyai kekuatan kepada yang tidak memiliki daya, dengan tujuan menyebabkan distres demi kepuasan dirinya. Menurut Tattum (1998), bullying adalah keinginan, kesadaran untuk menyakiti orang lain dan menyebabkan korban merasa dibawah tekanan stres. Menurut psikolog Andrew Mellor (dalam Setyawan, 2014), bullying adalah 
pengalaman yang terjadi ketika seseorang merasa teraniaya oleh tindakan orang lain dan ia takut apabila perilaku buruk tersebut akan terjadi lagi sedangkan korban merasa tidak berdaya untuk mencegahnya.

Berdasarkan definisi beberapa ahli tersebut, dapat disimpulkan bahwa bullying adalah bentuk perilaku anti sosial yang dilakukan oleh individu dengan jalan memberikan perlakuan berupa tindakan atau perkataan kepada orang lain (korban) untuk mendapatkan kepuasan diri, serta memberikan dampak negatif pada fisik dan psikis korban.

Salah satu penyebab bullying adalah individu kurang memiliki keterampilan pemecahan masalah. Arbor (2002) menyatakan terkadang individu yang menghadapi situasi sulit di rumahnya, seperti perceraian, atau di sekolah akan melakukan bullying kepada individu lain agar merasa lebih penting atau mengendalikan peristiwa hidupnya. Umumnya, pelaku bullying di sekolah adalah individu yang memiliki penghargaan diri yang rendah dan mencari penghargaan popularitas. Senada dengan pernyataan tersebut, Gross (2014) menyatakan salah satu penyebab individu menjadi pelaku bullying adalah individu yang dilupakan. Individu membutuhkan cinta dan perhatian dari orang dewasa yang peduli terhadap mereka, mereka ingin dan membutuhkan hal tersebut terutama dari ibu dan ayahnya. Tidak ada satu orang pun yang lebih penting dari ayah dan ibu, anak akan berusaha mendapatkan perhatian dari ibu dan ayah, sejak dia lahir sampai mati. Kondisi tersebut merupakan masalah bagi individu. Jika mereka tidak mendapatkan cinta dan perhatian di rumah, mereka dapat mengalami ketidakmampuan berbicara dan merasa tidak penting. Perasaan tersebut yang dapat berubah menjadi amarah, dendam, dan kemudian membully temannya di sekolah.

Masalah merupakan suatu kondisi yang senjang antara kenyataan dan harapan. Selain permasalahan kurangnya perhatian dan cinta dari orang tua, remaja juga mengalami masalah berkaitan dengan pribadi, sosial, akademik, dan karir. Kondisi pribadi misalnya kurangnya kepercayaan diri, manajemen emosi, kontrol diri dan sebagainya. Masalah sosial misalnya rendahnya penyesuaian diri, penerimaan sosial, dan perbedaan budaya. Pada bidang akademik misalnya tugas-tugas yang terlalu banyak, rendahnya kemampuan matematika, dan sebagainya. Sementara itu pada bidang karir misalnya kebingungan dalam memilih karir.

Jackson (2015) mengemukakan gagasannya tentang masalah adalah pusat dari apa yang kebanyakan orang lakukan setiap hari. Penyelesaian masalah untuk klien (internal atau eksternal), mendukung siapapun yang ingin menyelesaikan masalah, atau mengumpulkan informasi masalah baru untuk diselesaikan, masalah yang dihadapi dapat berupa masalah besar atau kecil, simpel atau kompleks, dan mudah atau sulit. Menurut Treffinger, dkk (dalam Steiner, 2009) masalah adalah sesuatu yang penting, terbuka, dan situasi yang ambisius untuk menentukan mana yang ingin dan butuh pilihan baru serta rencana untuk membawa solusi dengan berhasil. Sementara itu Hardin (2002) mengkategorikan masalah menjadi masalah yang baik, dan masalah yang berpotensi menjadi penyakit, berdasarkan bagaimana masalah dan tujuan digambarkan. Masalah dengan penggambaran yang berlainan dan tidak terbatas tujuan dinamakan masalah yang baik. Perbedaan yang jelas antara masalah yang baik dengan yang tidak adalah satu kesatuan, berdasarkan ragam masalah dan apa menghendaki pelibatan kognitif dalam penyelesaiannya.

Pada tahap remaja yang penuh dengan potensi, pengembangan keterampilan pemecahan masalah perlu dilakukan dalam situasi dan metode yang mampu membangkitkan kreativitas. Siswa seringkali dihadapkan pada masalah yang bersifat komplek, membutuhkan waktu yang segera untuk menyelesaikannya. Masalah jenis ini tidak hanya bisa diselesaikan dengan cara problem solving saja. Isrok'atun (2012) mengemukakan bahwa problem ini tidak dapat diselesaikan hanya dengan proses problem solving yang sudah kita kenal, tetapi siswa dituntut untuk membuat hubungan baru dari konsep yang ada untuk dapat membuat rencana penyelesaian. Tidak menutup kemungkinan, seandainya tidak membuat keterkaitan baru, problem tersebut terasa tertutup dari solusi yang diharapkan. Oleh karena itu, penting bagi siswa untuk memiliki kemampuan creative problem solving ini. Prinsip-prinsip dalam problem solving dielaborasikan dalam langkah kerja yang kreatif, inovatif, dan kekinian, yakni dalam pengembangan keterampilan pemecahan masalah secara kreatif (creative problem solving).

Mitchell \& Kowalik (1999) mendefinisikan creative problem solving sebagai proses, metode, atau sistem pendekatan masalah yang menggunakan jalan imajinatif dan menghasilkan tindakan efektif. Isaken (dalam Isrok'atun, 2012) mengemukakan bahwa creative problem solving tidak terbatas penyelesaian masalah. Fokus aspek kreatif yang dimaksud terletak pada menghadapi tantangan baru sebagai kesempatan, berhadapan dengan situasi yang tidak diketahui atau membingungkan, serta mengatur ketegangan yang 
disebabkan oleh ketimpangan antara keinginan dengan kenyataan secara produktif. Dalam penelitian ini, keterampilan problem solving yang dimaksud adalah sebagai aspek pribadi.

Untuk dapat meningkatkan keterampilan creative problem solving, siswa diberikan pelatihan dengan menggunakan langkah-langkah creative problem solving secara sistematis. Langkah tersebut adalah: (1) menemukan situasi, (2) menemukan fakta, (3) menemukan masalah, (4) menemukan gagasan, (5) menemukan solusi, dan (5) menemukan penerimaan (Osborn-Parnes dalam Isrok'atun, 2012), langkah tersebut dielaborasikan dengan menggunakan metode mind mapping, sehingga siswa tercegah dari perilaku bullying.

Agar dapat mencapai tujuan peningkatan keterampilan creative problem solving sebagai upaya pencegahan bullying, dikembangkan panduan pelatihan yang dapat digunakan oleh konselor dalam pelayanan bimbingan dan konseling. Panduan pelatihan yang dikembangkan memenuhi kriteria keberterimaan (Handarini, 2002), yakni: (1) ketepatan, (2) kegunaan, dan (3) keterlaksanaan. Oleh karena itu, peneliti melakukan pengembangan berjudul "Pengembangan Pelatihan Creative Problem Solving untuk Mencegah Bullying di SMP”.

\section{METODE}

Penelitian Pengembangan Panduan pelatihan creative problem solving untuk siswa SMP ini merupakan jenis penelitian dan pengembangan (Research and Development atau $\mathrm{R} \& \mathrm{D}$ ), yaitu metode penelitian yang digunakan untuk menghasilkan produk tertentu, dan menguji keefektifan produk tersebut. Analisis kebutuhan dilakukan untuk dapat menghasilkan produk tertentu dan untuk menguji keefektifan produk tersebut supaya dapat berfungsi di masyarakat luas, maka diperlukan penelitian menguji keefektifan produk tersebut (Sugiyono, 2011).

Borg dan Gall (1983) mengemukakan penggunaan sepuluh langkah dalam penelitian pengembangan, yang telah diterapkan oleh banyak peneliti. Langkah-langkah tersebut diadaptasi menjadi langkah-langkah berikut: (1) Melakukan penelitian dan pengumpulan data. Pada tahap ini dilakukan studi literatur dan pengumpulan data kebutuhan, (2) Mengembangkan produk. Pada tahap ini terdiri atas; (a) Merumuskan tujuan panduan pelatihan, (b) Menyusun prototipe produk berupa tujuan, materi pelatihan, prosedur, serta alat evaluasi, (3) Melakukan uji coba produk. Pada tahap ini diawali dengan menyusun alat penilaian berupa angket berskala untuk menilai ketepatan, kegunaan, dan keterlaksanaan. Kemudian, uji ahli dilakukan oleh tiga orang dosen bimbingan dan konseling yang memenuhi kriteria minimal pendidikan S2 BK, serta telah menjadi dosen minimal 5 tahun. Langkah selanjutnya adalah uji calon pengguna yang dilakukan oleh konselor dengan kriteria berprofesi sebagai konselor di SMP selama minimal 3 tahun, dan pendidikan terakhir minimal S1 BK, (4) Melakukan revisi produk berdasarkan penilaian ahli dan calon pengguna, (5) Menyajikan produk akhir berupa panduan pelatihan creative problem solving untuk mencegah bullying.

Instrumen yang digunakan untuk menilai produk berupa angket berskala yang memuat kriteria keberterimaan berupa ketepatan, kegunaan, dan keterlaksanaan. Hasil penilaian dianalisis menggunakan analisis kuantitatif dan deskriptif. Data kuantitatif ahli dan calon pengguna dianalisis menggunakan inter-rater agreement (Grinnell, 1988), sedangkan data deskriptif dianalisis berdasarkan masukan, saran, dan komentar pada lembar saran.

\section{HASIL}

Produk panduan pelatihan creative problem solving untuk mencegah bullying di SMP ini dikembangkan dalam format pelatihan sebanyak 12 kali pertemuan, yang masing-masing pertemuan memiliki tujuan dan strategi khusus. Peningkatan keterampilan creative problem solving yang dilakukan menerapkan langkahlangkah; (1) memahami masalah, (2) mengembangkan ide, (3) mengkaji ide, dan (4) mem-bangun penerimaan. Langkah-langkah creative problem solving tersebut diinternalisasikan dengan langkah-langkah dalam pembuatan mind mapping. Sehingga produk dari kegiatan pelatihan ini adalah berupa problem solving mapping. 
Tabel 1. Topik Creative Problem Solving

\begin{tabular}{lll}
\hline No. & \multicolumn{1}{c}{ Pertemuan } & \multicolumn{1}{c}{ Topik } \\
\hline 1 & Pertemuan 1 & Apa pemecahan masalah kreatif? \\
2 & Pertemuan 2 & Bullying perkataan \\
3 & Pertemuan 3 & Bullying perkataan \\
4 & Pertemuan 4 & Bullying fisik \\
5 & Pertemuan 5 & Bullying fisik \\
6 & Pertemuan 6 & Bullying dengan teknologi \\
7 & Pertemuan 7 & Bullying dengan teknologi \\
8 & Pertemuan 8 & Bullying hubungan pertemanan \\
9 & Pertemuan 9 & Bullying hubungan pertemanan \\
10 & Pertemuan 10 & Menjadi bagian berantas bullying \\
11 & Pertemuan 11 & Menjadi bagian berantas bullying \\
12 & Pertemuan 12 & Terminasi \\
\hline
\end{tabular}

Tabel 2. Hasil Penilaian Ahli dan Calon Pengguna

\begin{tabular}{|c|c|c|}
\hline Aspek & Penilaian ahli BK & Penilaian calon pengguna \\
\hline Ketepatan & $\begin{array}{l}\text { Dari } 8 \text { item penilaian, produk panduan } \\
\text { pelatihan ini berkriteria tepat dengan } 6 \\
\text { item memiliki persentase kesepakatan } \\
\text { sebesar } 66,67 \% \text {, } 2 \text { aspek lainnya } \\
\text { kesepakatan } 100 \%\end{array}$ & $\begin{array}{l}\text { Dari } 8 \text { item penilaian, produk } \\
\text { panduan pelatihan ini berkriteria } \\
\text { tepat dengan } 7 \text { item memiliki } \\
\text { persentase kesepakatan sebesar } \\
66,67 \% \text { dan } 1 \text { aspek memiliki } \\
\text { kesepakatan } 100 \%\end{array}$ \\
\hline Kegunaan & $\begin{array}{l}\text { Dari } 17 \text { item penilaian, produk } \\
\text { panduan pelatihan ini memenuhi } \\
\text { kriteria kegunaan dengan } 13 \text { item } \\
\text { memiliki persentase kesepakan } \\
\text { sebesar } 66,67 \% \text { dan } 4 \text { item memiliki } \\
\text { persentase kesepakatan } 100 \%\end{array}$ & $\begin{array}{l}\text { Dari } 17 \text { item penilaian, produk } \\
\text { panduan pelatihan ini memenuhi } \\
\text { kriteria kegunaan dengan } 16 \text { item } \\
\text { memiliki persentase kesepakatan } \\
\text { sebesar 66,67 dan } 1 \text { item sebesar } \\
\text { 100\% }\end{array}$ \\
\hline Keterlaksanaan & $\begin{array}{l}\text { Dari } 5 \text { item penilaian, produk panduan } \\
\text { pelatihan ini memenuhi kriteria } \\
\text { keterlaksanaan dengan } 2 \text { item } \\
\text { memiliki persentase kesepakatan } \\
66,67 \% \text { dan } 3 \text { item memiliki } \\
\text { persentase kesepakatan } 100 \%\end{array}$ & $\begin{array}{l}\text { Dari } 5 \text { item penilaian, produk } \\
\text { panduan pelatihan ini memenuhi } \\
\text { kriteria keterlaksanaan dengan } 2 \text { item } \\
\text { memiliki persentase kesepakatan } \\
66,67 \% \text { dan } 3 \text { item memiliki } \\
\text { persentase kesepakatan } 100 \%\end{array}$ \\
\hline
\end{tabular}

Produk yang dikembangkan tersebut merupakan panduan untuk konselor sebagai rujukan untuk memberikan pelatihan creative problem solving. Adapun isi panduan tersebut adalah:

1. Pendahuluan. Pada bab ini memuat rasional pengembangan panduan, tujuan, prosedur pelaksanaan, serta bentuk evaluasi.

2. Prosedur pelaksanaan pelatihan. Pada bab ini diuraikan strategi pelatihan yang terdiri dari 12 pertemuan. Adapun rincian topik creative problem solving dapat dilihat pada tabel 1. Masing-masing pertemuan secara umum terdiri atas tahap pembentukan, peralihan, inti, dan penutup selama maksimal 120 menit. Untuk mengurangi kekakuan dalam sesi pelatihan, di dalam buku panduan juga memuat strategi ice breaking yang bisa digunakan di tahap peralihan.

3. Daftar Rujukan. Memuat beberapa sumber baik berupa buku, informasi dalam website, dan jurnal yang dapat dijadikan sebagai rujukan peningkatan wawasan konselor tentang creative problem solving dan bullying. 
4. Lampiran. Pada bagian lampiran, diuraikan jabaran materi tentang creative problem solving yang disampaikan pada pertemuan pertama, serta langkah-langkah evaluasi secara afektif dan psikomotor. Sedangkan pada aspek kognitif ditelusuri pada pertemuan ke 12.

Untuk dapat mendukung visualisasi panduan pelatihan, buku panduan disertai dengan gambar-gambar tema yang sesuai dengan topik bahasan dengan menggunakan beberapa warna. Misalnya pada topik bullying fisik menggunakan gambar tema seorang siswa yang dipukul oleh rekan-rekannya. Panduan ini dicetak di kertas dengan ukuran A5 dan berjumlah halaman 130. Hasil penilaian ahli dan calon pengguna dapat dilihat di tabel 2.

\section{PEMBAHASAN}

Berdasarkan hasil penilaian yang dilakukan oleh ahli dan calon pengguna produk pada aspek ketepatan, tujuan dan rasional pentingnya pelatihan creative problem solving untuk mencegah perilaku bullying dirumuskan dengan sangat tepat. Merujuk pada pendapat yang dikemukakan oleh Arbor (2002) bahwa individu yang melakukan bullying bisa terjadi karena ia mengalami permasalahan di rumah seperti perceraian, atau masalah lain di sekolahnya. Rasional dijabarkan dengan memuat fenomena bullying serta kaitannya dengan aspek penyelesaian masalah secara kreatif.

Pelatihan creative problem solving yang disusun berdasarkan aktivitas penyelesaian masalah dengan menerapkan langkah-langkah creative problem solving yang dielaborasikan dengan strategi mind mapping. Langkah creative problem solving yang digunakan dalam pelatihan ini sesuai dengan yang dikemukakan oleh Osborn dan Pearnes (dalam Isrok’atun, 2012), antara lain: (1) menemukan situasi, (2) menemukan fakta, (3) menemukan masalah, (4) menemukan gagasan, (5) menemukan solusi, dan (6) menemukan penerimaan. Tahap ini dinilai sangat tepat karena solusi yang dibuat berdasarkan atas pemahaman individu terhadap kondisi diri, baik situasi yang dihadapi, dukungan, serta hambatan. Selain memuat kriteria sangat tepat, langkah-langkah tersebut juga dinilai praktis (mudah dilaksanakan) jika diterapkan di jenjang SMP dengan persentase kesepakatan $100 \%$.

Penggunaan bahasa dan dukungan gambar-gambar dalam buku panduan pelatihan creative problem solving untuk mencegah bullying oleh ahli dan calon pengguna dinilai tepat, dengan kriteria kesepakatan tinggi. Begitu juga dengan topik yang menjadi bahasan dalam kegiatan pelatihan. Topik yang dikemukakan dalam panduan pelatihan ini merupakan permasalahan yang umumnya terjadi pada remaja di sekolah menengah pertama (SMP). Storey \& Slaby (2013) mengategorikan bullying menjadi empat bentuk, yaitu; (1) verbal, (2) fisik, (3) relational, dan (4) cyberbullying. Senada dengan hal tersebut, berdasarkan hasil analisis angket perilaku bullying yang umumnya terjadi di SMP Negeri 20 Malang adalah keempat bentuk bullying tersebut dengan persentase yang berbeda-beda. Bullying verbal menduduki persentase tertinggi disusul fisik, relational, dan cyberbullying.

Dalam buku Penataan Profesional Konselor dalam layanan BK di jalur pendidikan formal, problem solving merupakan salah satu fokus pengembangan dalam layanan dasar bimbingan dan konseling. Merujuk pada hasil penilaian ahli dan konselor terhadap produk, panduan ini memenuhi kriteria kegunaan serta berdampak pada layanan bimbingan dan konseling. Dampak tersebut bukan hanya untuk konselor sebagai pemberi layanan saja, tetapi juga untuk siswa untuk menciptakan lingkungan sekolah yang kondusif.

Berdasarkan penilaian ahli dan calon pengguna pada aspek kegunaan, kompetensi konselor turut memengaruhi seberapa berguna panduan pelatihan tersedia. Ahli BK dan calon pengguna (konselor) memberikan kesepakatan tinggi bahwa pelatihan harus dilaksanakan oleh konselor yang memiliki kompetensi. Geldard \& Geldard (2011) menyebutkan bahwa dasar perilaku yang harusnya dimiliki oleh konselor ketika bekerja untuk anak muda mencakup; (1) bersikap responsive terhadap kebutuhan perkembangan anak muda, (2) memercayai anak muda, (3) memadukan diri dalam gaya komunikasi remaja, (4) bersikap proaktif, dan (5) menghormati proses anak muda dalam mengungkap dirinya. Hal tersebut menjadi perhatian bagi konselor akan pentingnya kompetensi diri dalam memberikan layanan bimbingan dan konseling.

Penggunaan bahasa dalam perumusan rasional, tujuan, topik, contoh kasus sebagai bahan penyelesaian masalah secara kreatif, dan evaluasi dinilai oleh ahli BK dan calon pengguna (konselor) sudah memenuhi 
kriteria keberterimaan. Selain menggunakan bahasa yang sesuai dengan kaidah Ejaan Yang Disempurnakan (EYD), dalam buku panduan menggunakan bahasa yang sesuai dengan karakteristik dan perkembangan siswa SMP.

Berdasarkan penilaian ahli dan calon pengguna pada aspek keterlaksanaan, efisiensi penggunaan tenaga dalam pelaksanaan pelatihan, diperoleh skor 3 dan 4, dengan interpretasi panduan ini efisien dari segi penggunaan tenaga. Aktivitas pelatihan disusun dengan strategi bimbingan kelompok secara umum dengan tahap pembentukan, peralihan, tahap inti (kerja), dan penutup. Peran konselor adalah sebagai fasilitator, yang memberikan instruksi serta membimbing aktivitas siswa. Sedangkan siswa sebagai subjek utama dalam kegiatan pelatihan, yang terlibat secara konstan, baik di tahap pembentukan, peralihan, dan penutup.

Pada aspek efisiensi penggunaan waktu, ahli BK dan calon pengguna (konselor) memberikan penilaian panduan ini efisien. Dalam panduan pelatihan creative problem solving, kegiatan pelatihan disusun berdurasi 100-120 menit setiap pertemuannya, dengan total pelatihan sebanyak 12 kali pertemuan. Pelatihan yang dimaksud merupakan salah satu layanan dasar bimbingan dan konseling yang diberikan kepada siswa di luar jam klasikal (masuk kelas). Pelatihan ini memang tidak memungkinkan jika diberikan kepada siswa di dalam jam klasikal (1 x 40 menit).

Pada aspek efisiensi penggunaan biaya, pelatihan ini dinilai oleh ahli BK dan calon pengguna efisien dengan persentase kesepakatan $66,67 \%$. Setiap pertemuan, alat yang dibutuhkan adalah spidol warna, kertas HVS, dan jika memungkinkan adanya fasilitas LCD dan Proyektor untuk menampilkan contoh kasus. Tetapi hal tersebut dapat diantisipasi dengan teknik lain, misalnya menggandakan contoh kasus untuk siswa.

Selain penilaian dalam bentuk kuantitatif, penilaian dilakukan berdasarkan kritik, saran, dan masukan ahli dan calon pengguna, tetapi saran tersebut dipertimbangkan dan dianalisis sebelum dilakukan revisi produk. Tata bahasa dan penulisan dalam produk direvisi berdasarkan saran dari ahli, karena produk sebelumnya masih terdapat banyak salah penulisan serta ketidaktepatan istilah yang digunakan dalam produk panduan. Pertemuan akhir dalam pelatihan dilakukan revisi dengan menambahkan aktivitas yang menekankan pada hasil dan kesimpulan pelatihan selama 12 kali pertemuan. Selain itu revisi juga dilakukan pada salah satu aktivitas ice breaking yang menggunakan lagu. Dosen uji ahli BK mengemukakan bahwa aktivitas tersebut tidak memenuhi kriteria kemudahan. Pertimbangan lain adalah bahwa tidak semua konselor mengetahui dan memahami lagu tersebut. Aktivitas tersebut juga dinilai memberatkan konselor karena membutuhkan alat pengeras suara dalam pelaksanaannya.

\section{SIMPULAN DAN SARAN}

\section{Simpulan}

Berdasarkan hasil uji ahli dan calon pengguna, panduan ini dinilai telah memenuhi kriteria keberterimaan, yaitu ketepatan, kegunaan, dan keterlaksanaan, masing-masing yakni aspek ketepatan (tinggi), kegunaan (tinggi), dan keterlaksanaan (sangat tinggi). Oleh karena itu, panduan pelatihan ini dapat dijadikan sebagai media pelayanan bimbingan dan konseling oleh konselor.

\section{Saran}

Konselor dapat menggunakan panduan pelatihan creative problem solving ini untuk mencegah terjadinya bullying di SMP dengan menerapkan dalam kegiatan penelitian tindakan Bimbingan dan Konseling. Pengembangan panduan ini sampai pada tahap uji ahli dan calon pengguna, sehingga dapat dilanjutkan dengan menggunakan penelitian kuantitatif eksperimen untuk mengetahui efektifitas penerapan panduan pelatihan oleh konselor maupun peneliti lain. Selain itu, berdasarkan saran dari ahli BK, perlu adanya pengembangan panduan pelatihan creative problem solving untuk mencegah perilaku-perilaku malasuai lainnya. 


\section{DAFTAR RUJUKAN}

Arbor, A. 2002. Why Do Some Kids Become Bullies? (Online). (med.umich.edu/opm/news-page/bullies.htm, Diakses 1 November 2015).

Besag, V.E. 1994. Bullies and Victims in Schools. Philadelphia: Open University Press.

Borg, W.R \& Gall, D. 1983. Educational Research. New York: Longman Inc.

Geldard, K \& Geldard, D. 2011. Konseling Remaja Pendekatan Proaktif untuk Anak Muda. Alih Bahasa oleh Eka Adinugraha. Yogyakarta: Pustaka Pelajar.

Gross. G. 2014. What Causes Your Child to Become a Bully?. (huffpost.com/us/entry/5980002, Diakses 1 November).

Handarini. D.M. 2000. Pengembangan Model Keterampilan Sosial bagi Siswa Sekolah Menengah Umum Terpadu. Disertasi tidak diterbitkan. Malang: Pascasarjana UM

Hardin, L. E. Journal. 2002. Problem Solving Concept and Theory. Journal of Veterinary Medical Education, (Online), 30 (3):227-230, (http://www.utpjournals.com, diakses 12 September 2015).

Isrok'atun. 2012. Creative Problem Solving (CPS) Matematis. Makalah dipresentasikan dalam Seminar Nasional Matematika dan Pendidikan Matematika dengan tema "Kontribusi Pendidik-an Matematika dan Matematika dalam Mem-bangun Karakter Guru dan Siswa” pada tanggal 10 November 2012 di Jurusan Pendidikan Matematika FMIPA UNY.

Jackson, K. 2015. What is Problem Solving?. (Online). (https://www.mindtools.com/pages/article/ newTMC 00.htm, Diakses tanggal 19 Maret 2015).

Kartadinata, dkk. 2008. Penataan Pendidikan Profesional Konselor dan Layanan Bimbingan dan Konseling dalam Jalur Pendidikan Formal. Bandung: Dirjen DIKTI

Mitchell, W.E \& Kowalik, T.F. 1999. Creative Problem Solving. New York: Genigraphics Inc

Setyawan, D. 2014. KPAI: Kasus Bullying dan Pendidikan Karakter. (Online). (http://www.kpai.go.id/ berita/kpai-kasus-bullying-dan-pendidikan-karakter/, Diakses 26 Februari 2015).

Steiner, G. Journal. "The Concept of Open Creativity: Collaborative Creative Problem Solving for Innovation Generation-a System Approach”. Journal of Business and Management.15,(1), 5-33.

Storey, Kim \& Ron Slaby. 2013. Eyes on Bullying. Waltham. Education Development Center, Inc Sugiyono. 2011. Metode Penelitian Kuantitatif, Kualitatif, dan R\&D. Bandung: Alfabeta.

Tattum, D, et al. 1993. Understanding and Managing Bullying. Oxford: Clays Ltd, St. Ives plc. 